\title{
Povijesni razvoj i važnost djelovanja hrvatskoga Orlovstva
}

\author{
Saša Ceraj*
}

\begin{abstract}
Sažetak
Slijedom provedenog znanstvenog istraživanja utvrdenog na arhivskim izvorima, članak donosi povijesno-kronološku raščlambu djelovanja, osamostaljenja i ujedinjenja hrvatskoga Orlovstva te vrednuje formativne faze djelovanja koje su uključivale stvaranje institucionaliziranih oblika udruživanja Orlova. Ovim se radom po prvi puta iznosi detaljan prikaz djelovanja hrvatskoga Orlovstva, od početaka do ujedinjenja u jedinstvenu organizaciju pod nazivom Hrvatski orlovski savez te konačnog ukidanja uslijed uvođenja Šestosiječanjske diktature 1929. godine. Na taj način, rasvjetljava se prostor djelovanja hrvatskoga Orlovstva, posebice Hrvatskog orlovskog saveza, što do sada nije detaljnije analizirano niti cjelovito predstavljeno znanstvenoj zajednici. Stoga je predstavljanje razvoja hrvatskoga Orlovstva potrebno s obzirom na pripadnost navedene teme nedovoljno obrađenomu i nedostatno istraženomu interesnom području te se ovim radom ostvaruje nov prinos $i$ vrednuje uloga orlovskoga pokreta u Hrvatskoj.

Ključne riječi: Orlovstvo, hrvatsko Orlovstvo, Ivan Merz, Hrvatski orlovski savez, hrvatska orlovska posebnost
\end{abstract}

\section{Uvod}

Značajke razvoja hrvatskoga Orlovstva uvelike su ovisile o kulturološkim i nacionalnim posebnostima, ali i o općim društvenim odrednicama koje su odgovarale prilikama društava poslije Prvoga svjetskog rata, što je utjecalo i na hrvatske okolnosti. Naime, Orlovstvo preko Slovenije dolazi u Hrvatsku kao odgovor na pojavu liberalizma i sokolske organizacije, nadovezujući se na Hrvatski katolički pokret predvođen krčkim biskupom Antunom Mahnićem koji se usprotivio novonastalim pojavama u društvu osnivanjem časopisa »Hrvatska straža« 1903. kao svojevrsnim početnim impulsom društvenoga organiziranja. ${ }^{1} \mathrm{U}$ Beču se iste go-

* Dr. sc. Saša Ceraj, ravnatelj Hrvatske olimpijske akademije. Adresa: Trg Krešimira Ćosića 11, 10000 Zagreb, Hrvatska. E-pošta: sasa.ceraj@hoo.hr

1 Sokolstvo predstavlja tjelovježbeni pokret koji se od 1862. godine razvija u slavenskim zemljama, a »nosioci pokreta svuda su liberalno usmjereni građanski slojevi« društva [Bez autora], Sokolstvo, Enciklopedija fizičke kulture - svezak 2, Zagreb, 1977, 278. O hrvatskom Sokolstvu i 
dine osniva prvo akademsko društvo »Hrvatska «²; zatim se 1906. tiska đački list »Luč«, a u Zagrebu se osniva društvo »Domagoj« što predstavlja organizacijsku infrastrukturu na kojoj cee se razviti hrvatsko Orlovstvo. ${ }^{3}$

Slijedeća faza društvenoga organiziranja ponajviše okuplja omladinu koja će činiti potporne odrednice stvaranja novoga pokreta temeljenog na đaštvu kojem će se potom pridružiti mladi i visoko obrazovani ljudi te radnici kao temelj osnivanja »jedinstvene organizacije mladeži « ${ }^{4}$ staleške i klasne jednakosti. Time započinje stvaranje omladinske organizacije putem osnivanja omladinskih društava, međutim, još uvijek razvidno izostaje organizacijska utemeljenost na čvrstim odrednicama. Iako je navedene pokušaje društvenog organiziranja Prvi svjetski rat dokinuo, upravo su navedene aktivnosti predstavljale početke organiziranja koje će po završetku rata dovesti do obnove rada omladinskih društava - prethodnice i buduće bitne sastavnice hrvatskoga Orlovstva.

Po završetku Prvoga svjetskog rata poticaj za obnovu omladinskih društava dolazi od Hrvatskoga katoličkog narodnog saveza, dok na organizacijskom planu brigu o omladinskim društvima preuzima Narodni savez, uvodeći sustav i organizaciju rada vidljivu u osnivanju omladinskih sekcija i obnavljanju postojećih omladinskih društava, što ce dovesti do osnivanja Omladinskoga podsaveza i utjecati na budući razvoj Orlovstva. ${ }^{5}$

\section{Početci Orlovstva u Hrvatskoj poslije Prvoga svjetskog rata}

S paralelnim procesom revitalizacije omladinskih društava, javlja se orlovska misao koja sustavno okupljajući već postojeća đačka i omladinska društva, prerasta u organizaciju temeljenu na »jedinstvenom programu (...) i definiranom sistemu rada. $\ll^{6}$ Upravo će đačka organizacija predstavljati razvojni put stvaranja

njegovom usmjerenju više vidjeti: Orao [Ivan Merz], Na adresu »Hrvatskoga sokola«, Katolički list, 1925, 2, 20-21; Ivan Merz, Duh »Hrvatskoga sokola«, Orlovska straža, 1927, 1, 23-25.

2 »Prvi hrvatski katolički kongres, održan 3. - 5. rujna 1900. u Zagrebu, opširno se bavio socijalnim pitanjem u Hrvatskoj« te se može promatrati kao začetak promišljanja o nadolazećim promjenama. Nikola Jagetić, Orlovski pokret i zadrugarstvo, Organizacijski vjesnik, 1926, IV, 2, 14.; K. Eterović, Pismo katol. Hrv. omladini, Hrvatska straža, 1917, XV, [bez oznake broja], 133.; Ivo Protulipac, Hrvatsko orlovstvo, Zagreb, 1926, 56. Zanimljivo je istaknuti kako je Merz bio obnovitelj društva »Hrvatska « gdje je obnašao funkciju tajnika. Usp. Avelin Ćepulić, Iz đačkih dana dra Ivana Merza, Orlovska misao, 1927-1928, [bez oznake broja], 9, 130.

3 Fenomen hrvatskoga Orlovstva posebno je značajan kada se vodi računa o skromnim početcima i »maloj organizaciji iz koje je izrastao cijeli pokret, a glavni razlozi uspjeha prepoznaju se u jasnoći orlovskih načela i programa te sustavnosti i predanosti u radu i djelovanju.« Ivo Protulipac, Hrvatsko orlovstvo, Zagreb, 1926, 58; 105.

4 Isto, 59.

5 Omladinske sekcije u sklopu Narodnog saveza započinju s osnivanjem 20. veljače 1919. čime se uvodi sustav nove organizacije, a 24. travnja 1921. pristupilo se osnivanju Omladinskoga podsaveza koji će predstavljati daljnji organizacijski iskorak prema stvaranju uvjeta za prihvaćanje hrvatskoga Orlovstva. Isto, 60.

6 Orlovska organizacija - đaštvo i katolički pokret, [Vodstvo Hrvatskog orlovskog saveza i Sveze hrvatskih orlica], Zagreb, 1926, [bez str.]. 
hrvatskoga Orlovstva, na što će uvelike utjecati Dragutin Kniewald koji 1919. u đačke organizacije uvodi orlovske metode rada, nastojeći od samoga početka postići političku neovisnost. Navedenu odluku Dragutin Kniewald donosi prilikom sastanak u Zagrebu na kojem je sudjelovao i Ivan Merz, a izraziti će je u svome Dnevniku slijedećim riječima: »I moja je odluka bila gotova. U novoj šk. godini moram i u Senju osnovati mušku i žensku organizaciju katoličkog đaštva. Od politike bit ćemo daleko, to nije moj posao ni područje moga rada. Nastojat ćemo raditi religiozno i prosvjetno. «7 Poticaj i konačnu odluku uvođenja Orlovstva u Hrvatsku, Kniewald donosi nakon »tečaja hrvatske katoličke inteligencije koji se od 1. do 5. kolovoza 1919. održao u Homcu gdje je istaknuta misao o osnivanju Orlovstva $\ll^{8}$ u Hrvatskoj. ${ }^{9}$ Po završetku tečaja, gdje se upoznao s radom slovenskih Orlova, Kniewald dolazi u Senj i pristupa »osnivanju đačke orlovske i orlićke sekcije ${ }^{10}{ }^{10}$ ističući kako je »svoju odluku o osnivanju organizacije katoličkog đaštva u Senju proširio i produbio time, da će osnovati i orlovsku i orličku sekciju u budućoj organizaciji katoličkog đaštva u Senju.«11 Dok Kniewald osniva sekcije u Senju, u isto vrijeme u Zagrebu Pavao Jesih naglašava potrebu »oformljivanja orlovske ideje u sklopu hrvatske omladine « ${ }^{12}$, te se stoga organizacijski rad Kniewalda i Jesiha može sagledati kao početak Orlovstva u Hrvatskoj koje započinje u formi gimnastičkih odsjeka prosvjetnih društava i orlovskih i orličkih sekcija đačkih društava, međutim, još uvijek ne uvodeći orlovsko ime i znakovlje.

\section{Značenje Mariborskog sleta za razvoj hrvatskoga Orlovstva}

Uz mjestimične slučajeve osnivanja pojedinih orlovskih odsjeka u Hrvatskoj prije održavanja Mariborskog sleta, veliki organizacijski pomak bilježi se upravo po njegovu završetku, posebice putem organiziranja tečaja za Orlove-učenike i Orlice-učenice. ${ }^{13}$ Stoga organizaciju Mariborskog sleta valja promatrati u kontekstu odlučujućega utjecaja na budući razvoj Orlovstva u Hrvatskoj, s obzirom na to da je uz brojne međunarodne organizacije slet posjetila i hrvatska delegacija - sastavljena od vježbača gimnastičkih odsjeka đačkih društava koji su tom

7 Arhiv Ivana Merza, Ksaverska cesta 10b, Zagreb, (dalje AIM), Dnevnik dr. Dragutin Kniewald, [rukopis], 1919, 74.

8 Ivo Protulipac, Hrvatsko orlovstvo, Zagreb, 1926, 61.

9 A. Ćepulić, Socijalni tečaj u Homcu, Luč, 1919, XV, 1-2, 2. U svom Dnevniku Kniewald će zapisati: »Ta je moja odluka dobila novih snažnih pobuda u tečaju, što su ga, inicijativom dra Pere Rogulje, slovenski seniori priredili za hrvatske seniore na Homcu.« AIM, Dnevnik dr. Dragutin Kniewald, [rukopis], 1919, 74.

10 Fabijan Veraja, Hrvatski katolički pokret »potpuno zakazao i neuspio«?, Crkva u svijetu, 2005, XL, 3, 337.

11 AIM, Dnevnik dr. Dragutin Kniewald, [rukopis], 1919, 74.

12 Fabijan Veraja, Hrvatski katolički pokret »potpuno zakazao i neuspio«?, Crkva u svijetu, 2005, XL, 3, 338 .

13 Usp. Dragutin Kniewald, Dr. Ivan Merz —život i djelovanje, Zagreb, 1932, 159. 
prilikom po prvi put sudjelovali na orlovskome tečaju, uz pet tisuća simpatizera orlovske ideje. ${ }^{14}$

Međutim, osim orlovskoga tečaja kojim je orlovska tjelovježba odredila jedan od putova razvoja prema budućoj orlovskoj organizaciji u Hrvatskoj, formiran je i prvi privremeni odbor koji je predstavljao temelj budućega Saveza gimnastičkih odsjeka, a time i »prvu centralu hrvatskog Orlovstva «, 15 čime Orlovstvo u $\mathrm{Hr}$ vatskoj postaje »organizacija cjelokupne omladine, đačke i neđačke. « ${ }^{16}$ Značenje odrednice o hrvatskome Orlovstvu kao jedinstvenoj organizaciji cjelokupne omladine potrebno je sagledati u kontekstu tadašnje prakse dobno odijeljenih društava čime je Orlovstvo unijelo dodatnu novost na polju društvenoga organiziranja u Hrvatskoj. Potrebno je naglasiti kako je uz mušku granu prethodnice orlovskoga pokreta u vidu Sveze gimnastičkih odsjeka, organizacijski definirana i ženska grana putem društva pod nazivom Sveza gimnastičkih odsjeka, što je predstavljalo polazište daljnjega orlovskog razvoja koju će Kniewald naglasiti kao »klicu budućega hrvatskog Orlovstva.«17

Iako se Orlovstvo u Hrvatskoj širilo unutar raznih dobnih skupina, najveći razvoj bilježi se upravo u đačkom pokretu koji će kasnije predstavljati značajan dio Orlovstva koji se brzo širi obuhvaćajući cjelokupnu omladinu, potičući demokratsko djelovanje s ciljem odgoja svijesti o brizi za bližnjega te proklamirajući kulturni program i tjelovježbu koju omladina prima s posebnim interesom. ${ }^{18}$

Međutim, usprkos intenzivnomu radu i popularnosti, hrvatsko će se Orlovstvo suočiti s izraženim otporom, posebice prilikom osnivanja i učlanjivanja školske populacije u orlovska društva, što je uvelike sprječavala i onemogućavala službena državna politika. ${ }^{19}$ Osim otpora državnih vlasti, orlovski razvoj onemogućavale su i društvene organizacije, što se najviše očitovalo u pitanju pristupanja đačkoga pokreta u hrvatsko Orlovstvo, čemu se posebno protivila Jugoslavenska katolička đačka liga (Liga). S obzirom na to da je Liga poduzela sve kako đački pokret ne bi pristupio Orlovstvu, Kniewald odlučuje napustiti Ligu i posvetiti se

14 Po završetku sleta održani tečaj provodi se kao prvi hrvatski đački tehničko-organizacijski orlovski tečaj, a po završetku učesnici pod vodstvom Drage Zudeniga započinju s organizacijom Orlovstva u Hrvatskoj. Usp. Srijemski, Bit orlovstva, Luč, 1923, XVIII, 7-8, 150.

15 Privremeni odbor budućeg Saveza gimnastičkih odsjeka (SGO) formiran je 4. kolovoza 1920. što se može promatrati i kao datum osnivanja SGO-a, punim imenom Savez gimnastičkih odsjeka organizacija katoličkog srednjoškolskog đaštva. Orlovska organizacija - đaštvo i katolički pokret, [Vodstvo Hrvatskog orlovskog saveza i Sveze hrvatskih orlica], Zagreb, 1926, [bez str.].; Ivo Protulipac, Hrvatsko orlovstvo, Zagreb, 1926, 64.

16 Uz inicijativu sudionika tečaja, razvojni put budućeg hrvatskoga Orlovstva temeljen je i na objedinjavanju postojećih omladinskih društava ujedinjenih u Hrvatski katolički omladinski savez i omladinskih sekcija ujedinjenih u Hrvatski katolički narodni savez što će u konačnici rezultirati osnivanjem Saveza gimnastičkih odsjeka temeljenog na orlovskim smjernicama rada. Orlovska organizacija - đaštvo i katolički pokret, [Vodstvo Hrvatskog orlovskog saveza i Sveze hrvatskih orlica], Zagreb, 1926, [bez str.].

17 Fabijan Veraja, Hrvatski katolički pokret »potpuno zakazao i neuspio«?, Crkva u svijetu, 2005, XL, 3, 339.; Usp. Dragutin Kniewald, Dr. Ivan Merz — život i djelovanje, Zagreb, 1932, 159.

18 Usp. Ivo Guberina, Zelena knjiga, Zagreb, 1933, 106.

19 Usp. Zvonimir Dugački, Sveorlovski slet u Pragu 1929., Orlovski kalendar za prostu godinu 1929. 1929, VI, 1, 82. 
razvoju Orlovstva temeljenom na tjelesnom vježbanju, »religioznom životu « ${ }^{20} \mathrm{i}$ potpunoj apolitičnosti, što će prihvatiti i Ivan Merz određujući time jednu od sastavnica posebnosti hrvatskoga Orlovstva ${ }^{21}$.

\section{Jugoslavenska katolička đačka liga i odvajanje đačkoga pokreta}

Osnutak Lige veže se za 1919. godinu čime je ostvareno »povezivanjem hrvatskog i slovenskog Saveza katoličkog narodnog đaštva «22 u organizaciju sveukupnog katoličkoga đaštva predstavljajući time »važnu granu tadašnjeg Katoličkog pokreta «23, ali i savez jugoslavenskih katoličkih đačkih društava sa svrhom jedinstvenog organiziranja đaštva na katoličkim i demokratskim principima narodnog jedinstva. ${ }^{24}$ Začetci promjena i obrisi novoga smjera djelovanja omladinskih organizacija jasno se razaznaju u predavanju koje je 1923. godine na tečaju Lige održao Ivan Merz, označivši novi put utemeljen na provedbi Katoličke akcije, osamostaljenja i ujedinjenja hrvatskoga Orlovstva, nakon čega započinje masovno učlanjivanja đaka u orlovske sekcije koje će se s vremenom ujediniti u organizaciju pod nazivom Mahnićevo đačko orlovsko okružje. ${ }^{25}$

U skladu s organizacijskim poteškoćama uvjetovanim dvostrukim djelovanjem, javlja se ideja o napuštanju Lige i potpunome prelasku đaštva u hrvatsko Orlovstvo što je i učinjeno prilikom đačkoga orlovskog tečaja na Krapnju 1925. kada su izglasane »Krapanjske rezolucije « ${ }^{26}$ koje će poslužiti kao temelj novog razvoja idejne i organizacijske cjelovitosti orlovskoga đaštva unutar Mahnićeva đačkog orlovskog okružja kao članice Hrvatskoga orlovskog saveza. ${ }^{27}$ Prelazak đačkog pokreta u Orlovstvo temeljio se na zaključku o stvaranju jedinstvene đačke organizacije, pri čemu se u obzir naročito uzimala posebnost đačkoga pokreta

20 Fabijan Veraja, Hrvatski katolički pokret »potpuno zakazao i neuspio«?, Crkva u svijetu, 2005, XL, 3, 339.

21 Više vidjeti: Saša Ceraj, Prinos Ivana Merza oblikovanju posebnosti hrvatskoga orlovstva, $O b$ novljeni život, 2014, 69, 1, 39-50.

22 Božidar Nagy, Uzroci podjele u Hrvatskom katoličkom pokretu (Spor: Jugoslavenska katolička đačka liga — Hrvatski orlovski savez) — u: Zlatko Matijević (ur.), Zagreb, 2002, 644.

23 Slavko Šarić, Ivan Merz i provođenje Katoličke akcije u Hrvatskoj, Obnovljeni život, 1979, 34, 4, 340.

24 Liga je nastala kao ishod sastanka »Hrvatskog katoličkog đačkog saveza« i »Slovenske deijaške zveze « u koju su bila udružena katolička studentska društva, a za sjedište društva bio je određen Zagreb. Usp. A. O., Organizacija »Lige«, Luč, 1919, XV, 6-7, 42-44.; Vjekoslav Stella, Naši sastanci - Unifikacija jugoslavenskog katoličkog đaštva, Luč, 1919, XV, 1-2, 5.

25 Usp. Dragutin Kniewald, Dr. Ivan Merz — život i djelovanje, Zagreb, 1932, 143.

26 Krapanjskim rezolucijama željelo se urediti odnose između »Mahnićeve orlovske đačke organizacije i domagojske đačke organizacije, odnosno Jugoslavenske katoličke đačke lige. « Usp. Lav Znidarčić, Hrvatski katolički pokret i Hrvatska katolička akcija, — u: Zlatko Matijević (ur.), Hrvatski katolički pokret, Zagreb, 2002, 634.

27 Upravo su Krapanjske rezolucije rezultirale istupanjem đačkoga pokreta iz članstva u Ligi 1925. te potpunom orijentacijom đaštva prema radu u hrvatskom Orlovstvu. Usp. Slavko Šarić, Uspomene dr. Slavka Šarića na život i rad mladih katolika svoga vremena, Ivan Merz. Glasilo postulature za beatifikaciju Dr. Ivana Merza, Zagreb, 1985, 11-13, 1-3, 2-5. 
kao »samostalne kulturne organizacije « ${ }^{28}$ i nerazdvojivost đačkoga kulturnog i tjelovježbenog rada.

\section{Savez gimnastičkih odsjeka}

Iako i dalje bez orlovskoga nazivlja i financijskih sredstava, Savez gimnastičkih odsjeka (SGO) osnovan 4. kolovoza 1920. moguće je promatrati kao početak rada prve orlovske središnjice koja je okupljala gimnastičke odsjeke organizirane u sklopu »tadašnjih đačkih organizacija Lige. «29 Približavanje SGO-a Orlovstvu vidljivo je 12. prosinca 1920. kada pristupa slovenskoj orlovskoj svezi, što će dovesti do ubrzanoga razvoja orlovskog pokreta u Hrvatskoj, ali i početka »ideoloških razlika $\ll^{30}$, posebice na polju »vjersko-ćudorednog odgoja. «31 Želja za osamostaljenjem hrvatskoga Orlovstva posebno se očituje 1921. kada započinje rad na stvaranju organizacijske strukture i uređenju područja budućega djelovanja, a dodatne poteškoće proizlazile su iz još uvijek aktualne zabrane orlovskoga nazivlja.

SGO nije predstavljao isključivo tjelovježbeno društvo, već »kulturnu organizaciju temeljenu na idejnom pokretu kojemu je gimnastika predstavljala samo jedno od sredstava za postignuće ideala. «32 Usprkos zabrani orlovskoga nazivlja, đačka i omladinska društva učlanjivala su se u SGO djelujući kao gimnastički odsjeci s orlovskim predznakom te je već tada bilo vidljivo kako se Orlovstvo ne može ograničiti samo na tjelovježbu, jer bi na taj način negiralo vlastito »narodno, odgojno i organizacijsko «33 usmjerenje na čemu je upravo počivala reforma omladinskih organizacija i osamostaljenje orlovske organizacije.

Usprkos izrazito teškim uvjetima funkcioniranja, intenzivan rad SGO-a rezultirat će uvođenjem izdavačke djelatnosti na temelju koje započinje tiskanje »Vjesnika Saveza gimnastičkih odsjeka ${ }^{34}$ kao prethodnice budućih orlovskih glasila »Organizacijskog vjesnika « $\mathrm{i}$ »Orlovske straže« te raznih tiskanih tjelesnih vježbi. ${ }^{35}$ Navedene djelatnosti potrebno je promatrati u vidu neformalnih početaka hrvatskoga Orlovstva, a slijedeću fazu utvrđivanja Orlovstva predstav-

28 AIM, Zapisnik 33. redovite sjednice predsjedništva HOS - 8. IV. 1925., Zapisnici sa sjednica Hrvatskog orlovskog saveza, Zagreb, 16. prosinca 1923. - 3. kolovoza 1927., 34.

29 SGO je osnovan pod imenom Savez gimnastičkih odsjeka organizacija katoličkog srednjoškolskog đaštva, a 30. listopada 1920. preimenovati će se u Savez gimnastičkih odsjeka u koji se učlanjuju svi đački i omladinski gimnastički odsjeci. Slavko Šarić, Ivan Merz i provođenje Katoličke akcije u Hrvatskoj, Obnovljeni život, 1979, 34, 4, 340.

30 Isto.

31 Isto.; Ivo Protulipac, Hrvatsko orlovstvo, Zagreb, 1926, 64.

32 Ivo Protulipac, Hrvatsko orlovstvo, Zagreb, 1926, 66.

33 Isto.

34 »Vjesnik Saveza gimnastičkih odsjeka« počinje s izdavanjem u Zagrebu donoseći upute za rad društava i objavljujući mjesečne preglednice o njihovu radu. Ivo Protulipac, Hrvatsko orlovstvo, Zagreb, 1926, 65.

35 Usp. [Bez autora], Vijesti Sveze gimnastičkih odsjeka, Organizacijski vjesnik, 1924, II, 3, [bez str.]; [Bez autora], Vijesti Sveze gimnastičkih odsjeka, Organizacijski vjesnik, 1924, II, 4, [bez str.]. 
lja preoblikovanje SGO-a u Orlovski podsavez u Zagrebu, čime će gimnastički odsjeci postati orlovski odsjeci i upravo će se na taj način po prvi put službeno uvesti orlovsko nazivlje. ${ }^{36}$

\section{Orlovski podsavez u Zagrebu}

Nakon višegodišnjega rada na uvođenju Orlovstva, službeno orlovsko nazivlje dočekano je s velikim zanosom, ali ne i bez poteškoća koje su dodatno otežale rad hrvatskoga Orlovstva. ${ }^{37}$ Posebnu zapreku predstavljala je službena politika koja je početkom siječnja 1922. putem Povjereništva za prosvjetu i vjeru Kraljevine SHS u Zagrebu izdala zabranu sudjelovanja đaštva u Orlovstvu, na što hrvatsko Orlovstvo odgovara člankom »Pred novu borbu« definirajući navedenu odluku kao nasilan čin kojim se želi ugušiti razvoj hrvatskoga Orlovstva. ${ }^{38}$ Težinu zabrane potrebno je sagledati u kontekstu đačkoga pokreta kao brojnog dijela novoosnovanoga Orlovskog podsaveza, a zabrana je bila usmjerena na dokidanje cijele orlovske organizacije. Uz zabranu, teškoće u napretku Orlovskoga podsaveza ogledale su se u manjku materijalnih sredstava i odgovarajućega prosvjetnog kadra čime je komunikacija između orlovskih odsjeka bila znatno otežana, a novoosnivanim orlovskim okružjima u Osijeku, Đakovu, Splitu i Sinju državne su vlasti ubrzo onemogućile rad te su bila prisiljena rasformirati se. ${ }^{39}$

Zabrana pristupanja đaka u Orlovski podsavez dovela je u pitanje razvoj hrvatskoga Orlovstva, međutim, nakon višekratnih nastojanja hrvatsko Orlovstvo ponovno ostvaruje legalitet rada putem povlačenja zabrane, čime se orlovski rad pokreće u punome opsegu, što će vrlo brzo rezultirati napretkom Orlovskoga podsaveza posebno vidljivog na području izdavaštva, putem časopisa »Mladost « i rubrike »Orlovski pokret « koja objavljuje »pobudne članke, prijevod dijelova slovenske Zlatne knjige, te osnivanjem novinarske sekcije sa svrhom širenja orlovske ideje. « ${ }^{40}$ Usprkos povlačenju zabrane primanja đaka u Orlovstvo, Orlovski podsavez i dalje je predstavljao »uglavnom đačku organizaciju « ${ }^{41}$ uz paralelno djelovanje Hrvatskog katoličkoga omladinskog saveza kao samostalne organizacije čime nije ostvarena ideja o Orlovstvu kao organizaciji cjelokupne omladine. Proces okupljanja cjelokupne omladine započet će na glavnoj skupštini Orlov-

36 Usp. Ivo Protulipac, Hrvatsko orlovstvo, Zagreb, 1926, 69.

37 Usp. Priručnik Orlovske organizacije: Orlovska knjižica-Organizacijsko-idejni dio-Svezak 1, Osijek, 1923, 67-68.

38 Usp. Ivo Protulipac, Hrvatsko orlovstvo, Zagreb, 1926, 69.

39 Usp. [Bez autora], Vijesti Omladinskog podsaveza, Organizacijski vjesnik, 1923, I, 1, [bez str.]; Ivo Protulipac, Hrvatsko orlovstvo, Zagreb, 1926, 70.

40 Legalitet orlovskoga rada temeljio se na rješenju Ministarstva prosvjete od 6. veljače 1923. godine čime je zabrana rada Orlovstva de iure stavljena izvan snage. Međutim, de facto zabrana bit će u više prilika još uvijek na snazi putem često otvorenoga otpora profesora na školama koji su branili učenicima učlanjivanje u Orlovstvo. Ivo Protulipac, Hrvatsko orlovstvo, Zagreb, 1926, 70-72.; AIM, Zapisnik 41. redovite sjednice - 12. V. 1925, 38.

41 [Bez autora], Orlovstvo u prošloj godini, Mladost, 1925./26, VI, 1, 19. 
skog podsaveza gdje je i službeno iznesena ideja o udruživanju omladinske i đačke organizacije kao integralnog dijela hrvatskoga Orlovstva. ${ }^{42}$

Prije ujedinjenja, hrvatsko ce Orlovstvo morati prijeći još jednu razinu razvoja kao članice Jugoslavenske orlovske sveze (JOS) koja se 23. listopada 1921. godine osniva u Ljubljani, a po uređenju je predstavljala jedinstvenu organizaciju hrvatskoga Orlovskog podsaveza sa sjedištem u Zagrebu i slovenskoga Orlovskog podsaveza sa sjedištem u Ljubljani. ${ }^{43}$

\section{Hrvatski katolički omladinski savez i dr. Ivan Merz}

Hrvatski katolički omladinski savez (HKOS) osnovan je 1922. godine u Zagrebu koji je jednako kao i Orlovski podsavez bio učlanjen u Jugoslavensku orlovsku svezu, a njegovo osnivanje može se promatrati kao »produkt I. hrvatskog katoličkog (omladinskog) kongresa održanog 3. prosinca 1922. godine u Zagrebu $\ll^{44}$ te razvoja omladinskih društava. ${ }^{45}$

Odmah nakon povratka u Hrvatsku, Ivan Merz iskazuje interes za rad s mladima i uključuje se u rad Omladinskog saveza kojemu 3. prosinca 1922. godine postaje predsjednikom ${ }^{46}$ te se zalaže da Omladinski savez »bude impostiran na načelima Katoličke akcije, predstavljane po duhovnom savjetniku kojeg je trebala imati svaka organizacija. « ${ }^{47} \mathrm{Na}$ temelju navedenih smjernica i organizacijskog paralelizma u orlovskim, đačkim i omladinskim odsjecima, sve je više

42 Glavna skupština Orlovskoga podsaveza održana je prilikom Euharistijskoga kongresa 17. kolovoza 1923. u Zagrebu kada je utvrđeno novo predsjedništvo Orlovskoga podsaveza u koje su izabrani i djelatnici Omladinskoga saveza dr. Ivan Merz i o. Bruno Foretić. Za predsjednika je izabran dr. Josip Andrić, a za potpredsjednika Ivan Merz. Nakon skupštine, 20. kolovoza 1923. održan je i prvi orlovski nastup u vrtu nadbiskupskog sjemeništa u Zagrebu na kojem je sudjelovalo oko 200 Orlova i Orlica iz svih hrvatskih krajeva te Orlovi iz Slovenije, Sarajeva i Đakova. Ivo Protulipac, Hrvatsko orlovstvo, Zagreb, 1926, 72-73.

43 Ujedinjavanje hrvatskoga Orlovstva naglašeno je na sjednici Orlovskog podsaveza 30. studenoga 1922. i 29. travnja 1923. te na sjednici Omladinskog saveza. Usp. Isto, 74.

44 Prvi hrvatski katolički kongres u Zagrebu, Mladost, 1922, II, 11-12, 137.; Pavao Matijević, Omladinski savez, Mladost, 1922, II, 11-12, 129.

45 Omladinski savez predstavljao je udruženje hrvatskih katoličkih omladinskih i prosvjetnih društava i odsjek Hrvatskoga katoličkog narodnog saveza sa sjedištem u Zagrebu, a svrha mu je bila organiziranje hrvatske katoličke omladine na katoličkim načelima pri čemu nije imao političkih ciljeva. Statut društva donesen je na skupštini 18. veljače 1923., a odobren 2. ožujka 1923. od strane Nadbiskupskog stola rješenjem broj 2081 i Pokrajinske uprave za Hrvatsku i Slavoniju br. 11752-1923., od 17. ožujka 1923. Duhovnim savjetnikom udruženja imenovan je o. Bruno Foretić, D. I., a u potpisu pravila naveden je Ivan Merz kao predsjednik i Jerolim Malinar kao tajnik društva. Usp. [Bez autora], Pravila Omladinskog saveza, Mladost, 1923, III, 5, 59-62.; Ivo Rebersky, Jedno desetljeće, Orlovska straža, 1929, VII, 6-7, 138.

46 Merz se nakon završenoga studija na Sorboni vraća u Zagreb gdje »aktivno radi u katoličkim omladinskim organizacijama«, što će obilježiti početak velikih promjena na polju hrvatskoga Orlovstva. V. Božidar Nagy, Ivan Merz i Hrvatski orlovski savez — u: Zlatko Matijević (ur.), Hrvatski katolički pokret, Zagreb, 2002, 658.; D. Žanko, Svjetlo na gori, Orlovska straža, 1928, VI, 6, 163.

47 Fabijan Veraja, Hrvatski katolički pokret »potpuno zakazao i neuspio«?, Crkva u svijetu, 2005, XL, 3, 342 . 
jačala ideja o ujedinjenju hrvatskoga Orlovstva u jednu centralnu organizaciju. U skladu s tim, Omladinski savez organizirao je »II. Omladinski kongres « ${ }^{48}$ kao svojevrstan uvod u glavnu skupštinu Omladinskog saveza na kojoj je iznesena ideja o osamostaljenju i ujedinjenju hrvatskoga Orlovstva. Međutim, službena provedba ideje o osamostaljenju biti će realizirana 16. prosinca 1923. godine na izvanrednoj skupštini Upravnog odbora Omladinskog saveza koja je uslijedila nakon konstituirajuće sjednice Hrvatskoga katoličkog orlovskog saveza. Naime, na temelju inicijative Ivana Merza, Omladinski će se savez raspustiti i ujediniti u jednu orlovsku organizaciju čime započinje vrijeme intenzivnoga orlovskog rada i razvoja u Hrvatskoj. ${ }^{49}$

\section{Osnivanje Hrvatskoga orlovskog saveza}

Izvorno Orlovstvo predstavljalo je tjelovježbeni pokret koji je privlačio veliki broj mladih, već učlanjenih u omladinske organizacije, što je međutim dovelo do nepotrebnoga dvostrukog članstva, te između ostalog, uvjetovalo osnivanje Hrvatskog orlovskog saveza kao centralne i jedinstvene organizacije hrvatske katoličke omladine. ${ }^{50}$ Tako je Orlovstvo prema »Zlatnoj knjizi« predstavljalo »katoličku organizaciju hrvatske omladine sa svrhom združivanja u jednu četu hrvatske katoličke omladine koja će primiti obrazovanje na vjerskom, umnom, ćudorednom, socijalnom i tjelesnom polju čime su se ujedinile sve organizacije koje su djelovale na različitim poljima, a okupljale su mlade. «1

Provedba navedenih posebnosti osigurana je putem ujedinjenja Omladinskog saveza i Orlovskog podsaveza na zajedničkoj sjednici obaju vodstava čemu je prethodila konstituirajuća skupština Hrvatskog orlovskog saveza, kao »samostalne i jedine centralne organizacije za sva orlovska i omladinska društva « ${ }^{52}$ i

48 Drugi omladinski kongres održan je 18. kolovoza 1923. u Jeronimskoj dvorani u 13.30 sati na kojem je prisustvovalo 200 omladinaca iz različitih krajeva Hrvatske te predstavnici Francuske i Slovenije. [Bez autora], Kongres i glavna skupština Omladinskog saveza, Mladost, 1923, III, 8, 106.

49 Konstituirajuća sjednica Hrvatskoga katoličkog orlovskog saveza održana je u 8.30 ujutro dok je izvanredna skupština upravnog odbora Omladinskog saveza održana u 10 sati u prostorijama Hrvatskoga katoličkog narodnog saveza te se može pretpostaviti kako su odbornici obje organizacije prisustvovali skupštinama izbornih tijela. Usp. [Bez autora], Poziv na izvanrednu glavnu skupštinu Omladinskog saveza, Mladost, 1923, III, 12, 186.

50 »Orao je katolička prosvjetna i tjelovježbena uzgojna narodna omladinska organizacija, koja posebnim sredstvima obrazuje narodnu omladinu tako, da stvori kršćanski uzgojen, duševno i tjelesno zdrav, naobražen i organiziran narod.«Usp. Ivo Protulipac, Hrvatsko Orlovstvo, Zagreb, 1926, 9.; Božidar Nagy, Ivan Merz — apostol hrvatske mladeži (1896-1928), Susreti, 1986, 6, $39-49$.

51 [Bez autora], Zlatna knjiga hrvatske katoličke omladine, Orlovska knjižica — organizacijsko idejni dio, svezak 2, Zagreb, 1924, 7.; Ivo Protulipac, Hrvatsko orlovstvo, Zagreb, 1926, 9.

52 Sjednica je održana u nedjelju 16. prosinca 1923. godine u 8.30 sati u prostorijama Hrvatskog katoličkog narodnog saveza u Zagrebu, Kaptol 27/I. I. Protulipac, Na petu godišnjicu, Orlovska straža, 1929, VI, 1, [bez str.]; Ivo Protulipac, Hrvatsko orlovstvo, Zagreb, 1926, 74. 
»središte cjelokupne omladinske akcije u hrvatskim zemljama. $\ll^{53} \mathrm{Na} »$ konstituirajuću skupštinu « ${ }^{54}$ Hrvatskog orlovskog saveza pozvana su hrvatska katolička omladinska i prosvjetna društva, orlovska društva, orlovski odsjeci i druga društva s ciljem ujedinjavanja Orlovstva u jednu centralnu organizaciju pod prvotnim »imenom Hrvatski katolički orlovski savez «55 koje će se na istoj sjednici promijeniti u Hrvatski orlovski savez. ${ }^{56}$

Konstituirajuća skupština Hrvatskoga orlovskog saveza (Savez) odredila je privremeno predsjedništvo Saveza kojem je povjeren zadatak izrade novog »Poslovnika društva, a do donošenja novih propozicija na snazi su ostala pravila »Poslovnika « Jugoslavenske orlovske sveze, isključujući odredbe u suprotnosti s novim odredbama orlovskih društva i Hrvatskoga orlovskog saveza. ${ }^{57}$ Po završetku konstituirajuće skupštine, održana je i glavna skupština Omladinskog saveza na kojoj je određen prijenos omladinskih društava učlanjenih u Omladinski savez i cijeloga područja njegova djelovanja na Hrvatski orlovski savez.

Osamostaljenje i ujedinjenje hrvatskoga Orlovstva u novoosnovani Hrvatski orlovski savez predstavljalo je značajan organizacijski faktor za hrvatsko Orlovstvo kojem je uz raspršenost nedostajala jedinstvenost što je na ovaj način i postignuto. ${ }^{58}$ Ujedinjenje koje je obuhvatilo sva omladinska i orlovska društva preuzelo je u cijelosti i sav »vjersko-prosvjetni program Omladinskog saveza, a tjelovježbeni rad slovenskog Orlovstva postao je akcidentalnim sastavnim dijelom hrvatskog Orlovstva. «59 S obzirom na to da je proces ujedinjenja obuhvatio društva koja su se »razlikovala prema ustroju organizacije ${ }^{60}$, nužno je bilo prilagoditi i izmijeniti pravila prema odrednicama Hrvatskog orlovskog saveza što je jamčilo jedinstvenost pokreta, ali i jednostavnije djelovanje i centralno vodstvo. ${ }^{61}$

53 Ivan Merz, Nove smjernice omladinskog pokreta, Katolički list, 1920, [bez oznake godišta], 1, 10.

54 [Bez autora], Poziv na konstituirajuću glavnu skupštinu Hrvatskog katoličkog orlovskog saveza, Mladost, 1923, III, 12, 186.

55 AIM, Zapisnik Hrvatskog orlovskog saveza započet 16. XII. 1923., 1. Zapisnici sa sjednica Hrvatskog orlovskog saveza nastajali su od 16. prosinca 1923. do 3. kolovoza 1927.

56 Promjena imena biti će izglasana na prijedlog dr. Šimraka, a prije glasovanja o imenu dr. Merz je pojasnio razlog uključivanja pridjeva katolički u naziv nove organizacije, temeljeći opservaciju na činjenici kako se »katoličke organizacije po cijelom svijetu nazivaju katoličkim imenom pa čemu da Orlovi budu izuzetak.« Nakon što je izglasano novo ime Saveza pod nazivom Hrvatski orlovski savez, Merz je zatražio da se zapisnikom utvrdi njegovo stajalište odnosno njegov prijedlog imena — Hrvatski katolički orlovski savez. AIM, Zapisnik Hrvatskog orlovskog saveza započet 16. XII. 1923., 1.

57 Usp. [Bez autora], Konstituirajuća glavna skupština Hrvatskog orlovskog saveza, Mladost, 1924, IV, 1, 17; AIM, Zapisnik Hrvatskog orlovskog saveza započet 16. XII. 1923., 2.; [Bez autora], Nova Orlovska godina, Organizacijski vjesnik, 1924, II, 1, [bez str.]; Ivo Protulipac, Hrvatsko orlovstvo, Zagreb, 1926, 75.

58 Odobrenje ujedinjenja hrvatskoga Orlovstva u novu organizaciju izdao je preuzvišeni nadbiskup Bauer. Usp. AIM, Zapisnik Hrvatskoga orlovskog saveza započet 16. XII. 1923., 1.

59 Ivan Merz, Nove smjernice omladinskog pokreta, Katolički list, 1920, [bez oznake godišta], 1, 10.

60 [Bez autora], Nova pravila za društva, Organizacijski vjesnik, 1924, II, br. 6, [bez str.].

61 Usp. [Bez autora], Konstituirajuća glavna skupština Hrvatskoga orlovskog saveza, Mladost, 1924, IV $, 1,17$. 
Novitet koji je Hrvatski orlovski savez unio na područje omladinsko-orlovskog rada ogledao se u uključivanju onih društava koja nisu imala tjelovježbeni odsjek, za razliku od Orlovskog podsaveza u koji su mogla biti učlanjena samo ona društva koja su njegovala tjelovježbu. U skladu s tim, u novoosnovani Hrvatski orlovski savez »stupilo je uz 40 omladinskih i 20 đačkih orlovskih društava «62, zadržavajući »posebni đački odio koji će se kasnije formirati kao dio Hrvatskog orlovskog saveza pod imenom Mahnićevo đačko orlovsko okružje « ${ }^{63}$ te orlovska društva, katolička omladinska društva i orlovske odsjeke.

\section{Djelovanje Hrvatskoga orlovskog saveza}

Osnivanje Hrvatskoga orlovskog saveza predstavljalo je velik dobitak na idejnome planu jer je Savez ${ }^{64}$ kao dio programa preveo, preuredio i tiskao »Zlatnu knjigu « ${ }^{65}$ koja je precizno određivala vjerske i kulturne dužnosti članova društva, definirajući Orlovstvo kao »katoličku organizaciju hrvatske omladine «66 sa svrhom njezina udruživanja i odgoja u vjerskom, obrazovnom, umnom, ćudorednom, socijalnom i tjelesnom pogledu. Samim time »Zlatna knjiga« predstavljala je »idejno-duhovni priručnik hrvatskog Orlovstva sadržavajući sva vjerska i moralna načela kojih se član organizacije trebao držati i provoditi ih u životu«67

62 [Bez autora], Za Orlovstvo ili proti Orlovstva, Orlovska straža, 1926, IV, 5, 20.

63 Orlovska organizacija - đaštvo i katolički pokret, [Vodstvo Hrvatskoga orlovskog saveza i Sveze hrvatskih orlica], Zagreb, 1926, [bez str.].

64 »Zlatna knjiga«, autora Franca Terseglava, izdana je u Sloveniji 1910. godine, a hrvatsko izdanje objavljeno je 1924. godine koje je pripremio i nadopunio Ivan Merz, dok je prijevod sa slovenskog na hrvatski jezik bio povjeren Franu Biničkom. Usp. Dragutin Kniewald, Dr. Ivan Merz — život i djelovanje, 1932, 161. Uz predgovor, koji se smatra »carthom magnom Ivana Merza«, Merz je nakon prijevoda slovenskog izdanja unio izmjene temeljene na odrednicama Katoličke Akcije, dodajući posebno poglavlje o Crkvi i duhovniku »ispreplećući cijeli tekst s programom Katoličke akcije. «Razloge prerade i dopune »Zlatne knjige« Merz pripisuje novom razvoju mladih u skladu sa specifikumima hrvatskoga Orlovstva. Merz je u »Zlatnu knjigu« umetnuo nova poglavlja, posebice ona koja su se odnosila na područje duhovnosti te naročito na provedbu načela Katoličke akcije. Božidar Nagy, (ur.), Ivan Merz - Sabrana djela, svezak II., Zagreb, 2011, 74.; [Bez autora], Uz 60. obljetnicu uvođenja katoličke akcije u Crkvi u Hrvatskoj, Ivan Merz. Glasilo postulature za beatifikaciju Ivana Merza, 1985, 11-13, 1-3, 14-16. Uz navedena poglavlja dr. Merz u »Zlatnu knjigu« unosi i svoj poznati uvod koji je bio predmetom reakcija Seniorata, želeći hrvatsko Orlovstvo »prožeti do dna euharistijskim duhom i povezati ga usko s Crkvom." Slavko Šarić, Ivan Merz i provođenje Katoličke akcije u Hrvatskoj, Obnovljeni život, 1979, 34, 4, 341.

65 »Zlatna knjiga« bila je namijenjena životu i radu Orlova, prikazujući njihovo istinsko značenje i predstavljajući snažan socijalni i moralni korektiv društva, a hrvatskom je Orlovstvu pružila »svojevrstan vademecum « apostrofirajući duhovnu formaciju Orlova putem mota: »Žrtva — Euharistija — Apostolat«. Važnost »Zlatne knjige« prepoznao je i kardinal Alojzije Stepinac koji je još kao mladić bio član orlovske organizacije, a Božidar Nagy naglašava kako su upravo ideje iz »Zlatne knjige«, »pridonijele duhovnoj formaciji i potom životnoj orijentaciji mladog Stepinca prema svećenstvu.« Fabijan Veraja, Hrvatski katolički pokret »potpuno zakazao i neuspio«?, $\mathrm{Cr}$ kva u svijetu, 2005, XL, 3, 343.; Božidar Nagy, (ur.), Ivan Merz — Sabrana djela, svezak II., Zagreb, 2011, 75.

66 [Bez autora], Zlatna knjiga hrvatske katoličke omladine, svezak 2., Zagreb, 1924, 7.

67 Božidar Nagy, Ivan Merz — Sabrana djela, svezak II., Zagreb, 2011, 78. 
te je odredila »kompetenciju vrhovne crkvene vlasti (hrvatskoga episkopata) 68 nad Savezom. Time je Savez »Zlatnoj knjizi« odredio potpuno novo usmjerenje uz izostanak odredbi o slovenskome Orlovstvu, što je Merz objasnio novom samostalnošću hrvatskoga Orlovstva posebice u vjersko-prosvjetnom radu, dok je u »gimnastičko-tehničkom pogledu hrvatsko Orlovstvo nastavilo raditi u sporazumu sa slovenskom orlovskom braćom. «69

Međutim, datost hrvatske orlovske posebnosti utvrdio je Ivan Merz, koji nakon osnutka i po ovlaštenju Saveza, sastavlja pismo i šalje ga na adrese svih hrvatskih biskupija, obavještavajući ih o utemeljenju hrvatskoga Orlovstva slijedom enciklike Ubi Arcano Dei te posebno ističući ulogu svećenika u hrvatskome Orlovstvu, »ovisnost o biskupu i rad prema načelima Katoličke akcije koju određuje Sveta Stolica. ${ }^{70} \mathrm{Na}$ temelju Merzova prijedloga, Hrvatski orlovski savez u orlovska društva uvodi duhovnika kao zastupnika crkvene vlasti, a ne samo kao običnoga člana, što je do tada bila praksa u orlovskim organizacijama u drugim europskim zemljama. Merzovo pismo predstavlja novo usmjerenje i određenje hrvatskoga Orlovstva koje na taj način prerasta iz organizacije ograničene na djelovanje u sklopu uskoga polja tjelovježbe, u vjersko-kulturno-obrazovno-tjelovježbenu organizaciju sa široko razgranatim aktivnostima što će pridonijeti još intenzivnijem razvoju Orlovstva u Hrvatskoj. ${ }^{71}$

Prije osnutka Hrvatskog orlovskog saveza Orlovstvu je nedostajalo čvršće jedinstvo, a društva su osnivana kao samostalne pojave vezane uz svoje lokalne prilike bez jedinstvenog cilja. Osnutkom Hrvatskog orlovskog saveza među orlovska društva unesena je jedinstvena misao, zajednički cilj i osviještena ideja o zajedničkoj orlovskoj organizaciji. Hrvatsko se Orlovstvo nakon osamostaljenja i unifikacije posvetilo izgradnji i unapređenju snažne središnjice utemeljene na jedinstvu i disciplini te osiguravanju uvjeta kontinuiranog vodstva čime se omogućio neprekinuti razvoj prema unaprijed utvrđenim ciljevima.

Također, uz intenzivnu djelatnost u sklopu unifikacije i izgradnje snažne središnjice, Hrvatski je orlovski savez posebno brinuo o razvoju i napretku okružja, općina, društava, jedinstvenog tjelovježbenog sustava, programa i metoda rada, vršio organizacijski, prosvjetni i tjelovježbeni nadzor nad pojedinim okružjima, općinama i društvima te prikupljao statističke podatke o cjelovitosti hrvatskog Orlovstva. ${ }^{72}$ U skladu s tim prva godina rada Hrvatskog orlovskog saveza obu-

68 Ivan Merz, Nove smjernice omladinskog pokreta, Katolički list, 1920, [bez oznake godišta], 1, 11.

69 Isto.

70 Merz temeljem suglasnosti vodstva Hrvatskoga orlovskog saveza u mjesecu siječnju 1924. priprema prvi službeni akt Saveza pod nazivom »Pismo za biskupsku konferenciju « koje se može promatrati kao jedna vrsta deklaracije o odrednicama i usmjerenju daljnjega rada i djelovanja. Dragutin Kniewald, Dr. Ivan Merz — život i djelovanje, Zagreb, 1932, 162.; D. Žanko, Svjetlo na gori, Orlovska straža, 1928, VI, 6, 164.

71 Usp. [Bez autora], Nova Orlovska godina, Organizacijski vjesnik, 1924, II, 1, [bez str.].

72 Sjedište Hrvatskog orlovskog saveza nalazilo se u Zagrebu, Pejačevićev trg broj 15 (današnji Britanski trg) u zgradi Katoličkog djetićkog društva gdje su se nalazile dvije prostorije u kojima je bio smješten Savez, Nabavna zadruga, Mahnićevo đačko orlovsko okružje i privremeno Akademski Orao »Mahnić«. S obzirom na probleme financiranja Hrvatskoga orlovskog saveza, interijer 
hvatila je uređenje i jačanje cjelokupnog hrvatskog Orlovstva, održavanje tečajeva za omladince i đake, proslavu Orlovskog dana, smotru orlovskih redova za vrijeme ljetnih praznika, pokrajinskih javnih nastupa i zborova, intenzivirani prosvjetni rad u jesenskim i zimskim mjesecima te osnivanje novih orlovskih općina i okružja. ${ }^{73}$

\section{Ukidanje Hrvatskoga orlovskog saveza}

Nakon što je ukinuo »Vidovdanski ustav i uveo osobnu diktaturu «74 Kralj Aleksandar I. Karađorđević zabranio je rad političkih stranaka i raznih udruga čime su bila uključena i tjelovježbena društva te samim time i Hrvatski orlovski savez. Kralj je u Beogradu 5. prosinca 1929. godine na prijedlog ministara prosvjete, vojske i mornarice i predsjednika ministarskog savjeta propisao i proglasio Zakon o osnivanju Sokola Kraljevine Jugoslavije, odredivši rok od tri dana u kojem su se sva postojeća društva za fizički i moralni odgoj — između kojih se nalazio i Hrvatski orlovski savez — morala ujediniti u Sokol Kraljevine Jugoslavije ili će u protivnom biti ukinuta. ${ }^{75}$ Hrvatski su Orlovi $»$ pod pritiskom beogradske vlade i na savjet biskupa «76 odlučili raspustiti orlovsku organizaciju u koju je, u trenutku ukidanja, bilo učlanjeno više od 200 društava s oko 11000 članova. ${ }^{77}$

je bio skromno opremljen obuhvaćajući ono najnužnije poput stolova, stolica, ormara, arhive i pisaćih strojeva. Odbornici Hrvatskog orlovskog saveza bili su svakodnevno dužni dolaziti u prostorije Saveza i obavljati povjerena im zaduženja, a radno je vrijeme Saveza bilo od osam ujutro do osam navečer te nerijetko i do deset sati navečer. Međutim, Merz je znao vrlo često nastaviti raditi kod kuće do kasno u noć ne bi li riješio predmete koji se nisu stigli obraditi tijekom radnog vremena. [Bez autora], Vijesti Hrvatskog orlovskog saveza, Organizacijski vjesnik, 1924, II, 5, [str. bez oznake].; Leh Markov, U srcu hrvatskog Orlovstva, Orlovska straža, 1928, VI, 5, 147.

73 Uz programske i organizacijske poslove Hrvatski orlovski savez jedno je vrijeme bio angažiran oko pronalaska radnih mjesta i pružanju socijalne pomoći članovima, ali i onima koji nisu bili članovi hrvatskoga Orlovstva. Međutim, s obzirom na kompleksnost i nedostatnu opremljenost, nakon nekog vremena ta je zadaća dodijeljena Hrvatskom kršćanskom i socijalnom radničkom savezu iz Zagreba. [Bez autora], Vijesti, Orlovski vjesnik, 1928, I, 5, [str. bez oznake].; [Bez autora], Vijesti Hrvatskog orlovskog saveza, Organizacijski vjesnik, 1924, II, 2, [str. bez oznake].

74 Zlatko Matijević, Hrvatska pučka stranka i dr. Ivan Merz, Obnovljeni život, 1997, LII, 3-4, 235.

75 Uredbu o likvidaciju svih društava za fizički odgoj propisao je »ministar prosvjete i ministar vojske i mornarice u suglasnosti s predsjednikom ministarskog savjeta.« [Bez autora], Odredba o ukidanju dosadašnjih sokolskih i orlovskih organizacija, Orlovska straža, 1929, VI, 12, 259-260.; [Bez autora], Hrvatsko i jugoslavensko Sokolstvo, Orlovska straža, 1929, VI, 12, 260.

76 Fabijan Veraja, Hrvatski katolički pokret »potpuno zakazao i neuspio?«, Crkva u svijetu, 2005, XL, 3, 350 .

77 Hrvatsko Orlovstvo niti u jednom trenutku nije ugrožavalo državu, dapače, upravo ju je potpomagalo stvaranjem mladih, odgovornih i radišnih ljudi sa čvrstim i jasno definiranim moralnim stavovima, a često su i sami Orlovi potvrđivali ovu tezu odgovarajući na upit o rušenju institucija: »Što ću ja s tim institucijama i zašto da ih rušim? Ima samo jedna institucija koju želim osnovati u tebi, u Zagrebu i u svakom gradu i selu hrvatske domovine. To je institucija vjerne bratske ljubavi. Mi već imamo takvu instituciju i čuvati ćemo ju kao zjenicu oka svog: to je institucija orlovskog jedinstva, institucija orlovskog demokratizma.« Ilija Jakovljević, Smisao našeg demokratizma, Organizacijski vjesnik, 1926, IV, 2, 7.; I.[van] P.[rotulipac], Nakon pet godina, Orlovska straža, 1927, V, 12, 347.; [Bez autora], Hrvatsko Orlovstvo u godini 1926 - 7., Orlovska straža, 1927, V, 9, 271.; Ivan Merz, Osnivajmo orlovska i orlička društva!, Katolički tjednik, 1928, [bez oznake godišta], 3, 3 . 
Međutim, nakon raspuštanja Hrvatskog orlovskog saveza, »na prijedlog o. Josipa Vrbaneka osniva se nova organizacija po uzoru na francuske Križare «78 kojoj pristupaju bivši Orlovi i nove generacije mladih, predstavljajući time nastavak djelovanja hrvatskog Orlovstva u okrilju nove organizacije. ${ }^{79}$ Ideje i program rada hrvatskih Križara uvelike se oslanjao na djelovanje i postulate Hrvatskoga orlovskog saveza, a Križarska je organizacija nastavila djelovanje hrvatskoga Orlovstva izostavljajući samo tjelovježbu i ime, a zadržavajući članove, ciljeve, usmjerenje i program rada, predstavljajući životno djelo dr. Ivana Merza. ${ }^{80}$

\section{Zaključak}

Prodiranje liberalizma u Europu stvara reakciju koja se prepoznaje u europskim nacionalnim katoličkim pokretima i Orlovstvu kao protuteži koji se krajem 19. i početkom 20. stoljeća formira u Češkoj i Slovačkoj kao odgovor na Sokol. Orlovstvo preko Slovenije započinje djelovati i u Hrvatskoj gdje se promatra kao dio Hrvatskoga katoličkog pokreta, a razvoj hrvatskoga Orlovstva — kojem je prethodilo stiliziranje orlovske misli i filozofsko-organizacijskih pretpostavki - obuhvatit će više organizacijskih faza, posebno uočljivih u stvaranju različitih društava, što će kulminirati osnivanjem Hrvatskoga orlovskog saveza čime je određena organizacijska razina daljnjega razvoja, ali i snažno širenje orlovske misli na ovim prostorima. Osamostaljenje i ujedinjenje hrvatskoga Orlovstva predstavljala je nužnost jer dualistički model upravljanja i funkcioniranja omladinske i orlovske organizacije više nije bio održiv, a osim jedinstvene određenosti

78 Fabijan Veraja, Hrvatski katolički pokret »potpuno zakazao i neuspio?«, Crkva u svijetu, 2005, $\mathrm{XL}, 3,350$.

79 O nastavku djelovanja hrvatskog Orlovstva u vidu Križarske organizacije govori i dokument Republičkog sekretarijata unutrašnjih poslova koji u svojim izvještajima spominje na više mjesta preregistraciju hrvatskog Orlovstva: »Orlovstvo i njegov nasljednik Križarstvo (...).« Hrvatski državni arhiv (dalje: HDA), RSOUP SRH, 001. 4. 2., Domagojsko-seniorska organizacija - elaborat, str. 1.). Nadalje: »Križarska organizacija vuče svoje korijene (...) iz organizacije nazvane Orlovi (...). Poslije ukidanja orlovske organizacije pok. dr. Bauer nadbiskup zagrebački ustanovio je viševjersku organizaciju pod imenom Križari. To je zapravo bilo produženje orlovske organizacije pod drugim imenom i bez gimnastike u svom programu. Ukidanjem orlovske organizacije mnoga su se društva po provinciji raspala i nikada više oživljena.«HDA, RSOUP SRH, 001. 4. 4, Razvoj orlovsko križarske organizacije, 54.

80 Osnovana 1930. godine, Križarska organizacija djeluje do 1945. godine kada je »zbog nemogućnosti daljnjeg djelovanja raspušta tadašnji zagrebački nadbiskup Alojzije Stepinac« te ponovno započinje djelovati 1992. godine zahvaljujući zalaganju dr. Lava Znidarčića, dugogodišnjeg predsjednika Križarske organizacije. Od 1923. godine u muškoj križarskoj organizaciji »održano je 82.611 prosvjetnih sastanaka s 46.256 predavanja, 429 tečajeva, 1606 priredbi, 18. 392 odborskih sastanaka, 17000 članova i 9500 malih križara u muškom djelu organizacije.« Međutim, iako je umro prije osnivanja Križarske organizacije, hrvatsko Križarstvo smatra se »životnim dijelom Ivana Merza«. Božidar Nagy, Ivan Merz — apostol hrvatske mladeži (1896-1928), Susreti Zbornik radova Susreta hrvatskih studenata u tudini, 1986, [bez oznake godišta], 6, 39-49.; Josip Vrbanek, Vitez Kristov - Dr. Ivan Merz, Veliko križarsko bratstvo i Veliko križarsko sestrinstvo, 1943, 237.; Lav Znidarčić, Križarska organizacija, životno djelo Ivana Merza, Obnovljeni život, 1997, 52, 3-4, 251. 
hrvatsko se Orlovstvo povezalo s drugim zemljama gdje su živjeli Hrvati, posebno održavajući veze sa susjednim zemljama, čineći time Hrvatski orlovski savez središnjom organizacijom hrvatskoga Orlovstva. Nova se orlovska organizacija temeljila na vjerskim, kulturnim i programskim odrednicama, a jedinstveno usmjerenje odredit će Ivan Merz uvođenjem hrvatske orlovske posebnosti, vidljive u smjernicama Katoličke akcije, apolitičnosti, oduhovljenju tjelesne kulture te uvođenju svećenika-duhovnika u hrvatsko Orlovstvo. Do ukidanja Hrvatskoga orlovskog saveza dolazi u prosincu 1929. godine uvođenjem diktature kralja Aleksandra I. Karađorđevića koji je zabranio rad političkih stranaka i udruga Zakonom o osnivanju Sokola Kraljevine Jugoslavije čime su se postojeća društva za fizički i moralni odgoj morala ujediniti u Sokol Kraljevine Jugoslavije ili u protivnom biti ukinuta. Hrvatski orlovski savez navedenu diktaturu nije prihvatio, već se rasformirao i time bio ukinut nakon šest godina izrazito uspješnoga i plodonosnoga rada koji se ogledao u više od 200 orlovskih društava diljem zemlje i preko 11000 članova. 81

S obzirom na iznesene podatke utvrđene slijedom provedenoga znanstvenog istraživanja relevantnih arhivskih izvora, ovim se radom po prvi puta objedinjeno donose i rasvjetljavaju okolnosti osnivanja, kao i značaj formativnih faza djelovanja hrvatskoga Orlovstva, što predstavlja novi prilog razumijevanju ove važne tematike i područja koje do sada nije bilo cjelovito predstavljeno, te referentnu točku za daljnja istraživanja.

81 Usp. Ilija Jakovljević, Smisao našeg demokratizma, Organizacijski vjesnik, 1926, IV, 2, 7; I. P., Nakon pet godina, Orlovska straža, 1927, V, 12, 347; [Bez autora], Hrvatsko Orlovstvo u godini 1926-7., Orlovska straža, 1927, V, 9, 271; Ivan Merz, Osnivajmo orlovska i orlička društva!, Katolički tjednik, 1928, [bez oznake godišta], 3, 3 . 
The Historical Development and Importance of the Activities of Croatian Eagleship

\section{Saša Ceraj*}

\section{Summary}

In keeping with scientific research based on archival sources, the article puts forth a historical-chronological analysis of the activity, emancipation and unification of the Association of Croatian Eagleship and evaluates the formative phases of activity which included the creation of institutionalized forms of the Eagles' alliances. This article presents for the first time a detailed presentation of the activities of the Association of Croatian Eagles, from its beginnings up to their unification into a single organization called the Croatian Eagles' Federation and its ultimate elimination in the wake of the introduction of the January 6 Dictatorship in 1929. Thus, a light is cast upon the scope of activity of Croatian Eagleship, especially the Croatian Eagles' Federation which has until now not been analysed thoroughly, nor has it been integrally presented to the academic community. Hence, a presentation of the development of Croatian Eagleship is deemed necessary, since the subject matter may be classed as an insufficiently explored and researched field of interest, and so this article makes a new contribution thereto and evaluates the role of the Eagles' Movement in Croatia.

Key words: Eagleship, Croatian Eagleship, Ivan Merz, Croatian Eagles' Federation, distinctiveness of the Croatian Eagles

* Saša Ceraj, Ph.D., Director of the Croatian Olympic Academy. Address: Trg Krešimira Ćosića 11, 10000 Zagreb, Croatia. E-mail: sasa.ceraj@hoo.hr 